\title{
Bringing the Family Back in? Attitudes Towards the Role of the Family in Caring for the Elderly and Children
}

\author{
HEIKKI ERVASTI
}

\author{
Research Associate \\ Department of Social Policy \\ University of Turku \\ Turku, Finland
}

\begin{abstract}
In the last few years, demands for replacing the welfare state with family responsibility for the care of children and the elderly have become more and more insistent. Using data from a recent postal survey $(\mathrm{N}=1,737)$, the article's aim is to estimate the caring possibilities and caring potential of the family. The results show that compared to outside-home care and especially publicly provided outside-home care, family care is not supported by public opinion. However, the results provide no evidence of a decline in the caregiving potential of the family. Thus, the introduction of new family care-oriented policies and cuts in the public welfare services aimed at increasing family responsibility for the care of dependants could even be counterproductive, as families would soon be overloaded with caring tasks.
\end{abstract}

Keywords: welfare state, family responsibility, Finland

\section{Introduction $^{1}$}

Increasing the responsibility of the family in the care of the elderly and children has become an increasingly common topic in the present discussion on social policy. Traditionally, the neo-conservative critics of the welfare state have seen family care as an alternative to »unhealthy» government intervention in the everyday life of citizens and as a means to dismantle the caring systems of the welfare state. According to this point of view, the welfare state has inappropriately replaced the structures of support which naturally reside in the family. As the recession of the 1990s has set in, family care of children and the elderly has been proposed as a solution to the crisis of the welfare state. In particular, the cost of maintaining the present welfare state and the rising level of unemployment have led several authors to suggest that the respon-

${ }^{1}$ I wish to thank Olli Kangas, Kari Salavuo and Ismo Söderling for their helpful comments on an earlier draft. 
sibility for social care should be turned over to the family. Thus, not only conservatives but politicians of various persuasions are extolling the virtues of family care. (See Finch 1989, 237; Finch 1989a, 160; Taylor-Gooby 1991, 45-46; Waerness 1989a, 173; see also Lewis $1989,136$.

In sociopolitical discussion, however, several commentators have been quite skeptical about the option of replacing the welfare state by enhancing the functions of the family (e.g. Finch 1989; 1989a; Taylor-Gooby 1991). There are not only demographic and structural but also attitudinal restrictions to this option. As society has gone through structural changes, the role of the family has also changed. And even more important, our understanding of the concept of the family has also changed.

The chances of the family taking on more responsibility for caring not only depend on time and opportunity, but also on the normative judgments on which people base their actions. This is the point of departure of my article. As a standpoint, I assume that the caring potential of the family depends on how much people appreciate the social caring provided by family members compared to caring institutions outside the home. The aim of this article is to find out what kind of a caring commitment people want to give the family. Do people want to have more family care and less state care? Furthermore, organizing the caring systems of society depends on people's attitudes and values in a wider sense. Most important, increasing family responsibility is a question of gender roles. Do people want to go back to the traditional gender roles in their families or are new family and gender roles emerging?

The structure of my article is as follows: first, I shall have a look at the transformation of the family and its consequences for the change in the caring potential of the family. After that, I shall draw out several hypotheses about how men and women react to family care. Then I shall describe the survey data and methods used in the empirical analyses. Finally, in the concluding section, I shall present the results of my analyses and relate them to the present discussion on the role and possibilities of both the family and care within the family.

\section{The transformation of the family: a decline in caring potential?}

In order to answer the question of what the caring potential of the modern family is, we must first consider the transformation of the family. Not much seems to be left of the old-fashioned family described by the structural functionalists in the 1950s (e.g., Parsons and Bales 1955; see also Goldthorpe 1987, chapter 4), which was based on a breadwinning husband and dependent wife who together provided a harmonious, organic unit best able to meet the needs of an industrial society. Considerable changes have been witnessed over the last few decades in family life. There have been changes in women's employment, marriage, divorce, childbearing, parenting, and adult intergenerational relationships (Bumpass 1990, 483-484; Boh 1989; Castro Martin and Bumpass 1989,37$)$.

Marriages no longer necessarily last a lifetime. A high level of marital instability dominates core aspects of family life for the majority of the population. The number of single-parent families, usually headed by females, has also increased. More and more young children will be reared in a single-parent family, often as a consequence of divorce. On the other hand, remarrying generates new forms of family relationships, as more and more children have second parents and third grandparents. But perhaps the most potent force that has undermined traditional family arrangements in our society has been the rise in the proportion of women in paid work, especially those with young children. At the same time, and partly for the same reasons, families and households are getting smaller because fertility has decreased in almost all western countries. (Boh 
1989; Bumpass 1990, 485; Hulkko 1990, 5-9; Kamerman and Kahn 1989; Lindgren and Ritamies 1994, 133-135; 1987; Saari 1992; Scott, Braun and Alwin 1993, 25.)

There have been two kinds of interpretations of what the implications of the transformation of the family have been for the caring potential of the family. First, there has been widespread concern - especially among the neo-conservative commentators (e.g., Kramer 1983; Lindbeck 1986) - that the family is breaking up and thus unable to provide hardly any care for dependent family members. Mainly, the erosion of family responsibility has been blamed on the state. According to this thesis, the development of the welfare state has undermined the family, and this has happened against the citizens' will.

On the other hand, it has been argued that the family still provides the greatest amount of welfare. The increase in outside-home social welfare services has neither been able nor even intended to replace all reproductive functions of the family. Furthermore, despite the changes in society and in the family, there is no sign of the family abdicating its caring responsibilities. ${ }^{2}$ Nor is there any evidence to support the idea that there exists an unused pool of family caregivers who could be utilized by increased family care activities. Actually, as feminist social policy analysts have shown, more and more parents - particularly mothers - already juggle their time between work and family responsibilities (Dahlström 1989, 41; Lewis 1989, 134; Presser 1989, 523).

\section{Hypotheses}

The changes in the family and household have had mutually reinforcing effects as well as an impact on normative expectations about family life (see, e.g., Bumpass 1990, 483; Castro Martin and Bumpass 1989, 37). As stated above, normative judgments are of extreme importance in evaluating what the future strategy in social care and the caring potential of the family will be. Several previous studies have focused on these questions. In this section I shall discuss various hypotheses which explain differences in attitudes towards family-oriented social care. These hypotheses drawn from previous research deal with the effects of stratification hierarchies (most importantly gender and education), age, labor market experiences and ideology on attitudes towards family care.

Gender. The strategy of family care has substantial effects on gender roles. Increasing the responsibility of the family is not only a question of an alternative way of organizing care for the elderly and children, but it is also a question of gender roles, female dependency on the family and labor force participation of women.

Almost all previous studies emphasize the importance of gender in people's attitudes towards the role of the family and the responsibility of the family in social care. Previous research shows that without adequate consideration of gender as a variable as significant as the more traditional variables as education, labor market experiences, family situation and age, a policy analysis of this kind is likely to be fundamentally flawed (Lewis 1989,132$)$.

The question of family care is often seen as a conflict between the two genders. In this conflict, women struggle for independence from the family and from traditional gender roles. Accordingly, men are more likely to maintain or go back to the traditional roles (e.g., Waerness 1989a, 173). This hypothesis concerning women's struggle for independence can be accounted for by several arguments. Caregivers - be they

${ }^{2}$ According to the recent Vanhuusbarometri (Old age barometer 1994, 68), 85 percent of persons aged over 60 who receive regular assistance in their everyday life are helped by their family members and relatives. 
paid or unpaid workers - are usually women. Women are the major providers of welfare through their paid work as employees of the welfare state, but even more especially through their unpaid work at home (Lewis 1989,134$)$. Women participate in all domestic routines to a larger extent than men (Gershuny and Robinson 1988). As caring tasks are a type of family labor (see Finley 1989, 79; Waerness 1989, 217), there is no doubt that increasing the caring responsibility of the family would tie female members of the family to caregiving and even compel women back to the home from the labor market. Thus, female independence will lessen if the caregiving responsibility of the family is enhanced.

According to the women's struggle hypothesis, I would expect women to be more critical about family care than men. But, as there is evidence that women are more egalitarian than men in respect to gender role attitudes (Thornton, Alwin and Camburn 1983, 213), I also hypothesize that women want to transfer at least some of the caring responsibility onto the opposite sex. ${ }^{3} \mathrm{I}$ expect that women will be capable of increasing the caring responsibility of men.

The women's struggle hypothesis suggests that both genders but especially women are homogenous groups which are not cross-cut by other societal divisions. The women's struggle hypothesis ignores differences that might exist among both sexes in respect to various family situations, age, education level, labor market experience and political persuasion. These differences are the focus of the other hypotheses.

Education. Attitudes towards different policy strategies often depend strongly on location in stratification hierarchies (Ervasti and Kangas 1995; Svallfors 1989). Education can be viewed as one of the most important indicators of location in stratification hierarchies. Previous research shows that people with less education are more willing to support family care. This can be explained on the basis that these people have less challenging and less interesting jobs and a lower income than people with higher education. Thus, for example, the threshold for choosing to take care of children at home instead of participating in the labor force is lower among the less educated (Ervasti 1994, 283). Furthermore, highly educated persons may face greater depreciation of job-related skills from time out spent outside the labor force (see Desai and Waite 1991, 553).

It has been suggested that education increases awareness of gender inequality and rejection of traditional gender roles (Davis and Robinson 1991). According to Farkas (1976) high levels of education are associated with more equal sharing in all types of family labor. Thus, the well-educated will probably not want to increase the family care responsibility of women. On the other hand, less educated women may be more able to accept the role of family caregiver. More generally, it has also been suggested that men with low education and less prestigious occupations or low incomes may tend to view women as a threat in the competition for jobs. As a result, these men may support policies which probably decrease female labor force participation (Davis and Robinson 1991, 73). Moreover, less educated men may have more traditional opinions of the role of the family than men with higher education. Thus, I hypothesize that men with a lower education level support the idea of family care.

Age. In the previous studies, notable differences in gender role attitudes between age cohorts have been reported (e.g., Scott, Braun and Alwin 1993, 36). Thus, notable differences in family care attitudes can also be expected.

According to a theory known as the socialization hypothesis, younger generations have been socialized into more egalitarian gender roles than the older generations. The older generations were socialized into familist gender and family roles, according to

${ }^{3}$ Unfortunately, there is dearth of research on men's attitudes toward gender equality, especially in Finland. 
which strong family concerns are part of the feminine role and caregiving tasks are the responsibility of women. In contrast, the younger generations have been socialized into more individualistic family roles and egalitarian gender roles. The socialization of the younger age cohorts is related to the resurgence of feminism which began in the late 1960 s and early 1970 s. And more recently, the emergence of new social movements such as grassroots peace and ecology movements in the late 1970s and the formation of Green political parties with explicit feminist stands have politicized another generation as gender issues have been included in everyday politics. (See Davis and Robinson 1991, 73.) According to the socialization hypothesis, attitudes about gender roles affect attitudes about family responsibility to the elderly and children (Finley $1989,80)$. Thus, I hypothesize that younger age groups are more likely than the older age cohorts to reject the traditional family roles and family care provided by women.

However, the socialization hypothesis does not suggest that the younger generations totally and categorically reject the idea of family care. As a matter of fact, the new social movements have often preached a doctrine embracing informal, participative and unbureaucratic ways of organizing social caregiving (see Hadley and Hatch 1981). Family care may have some of these characteristics. Thus, the younger age cohorts may be more willing to share the family obligations between the two sexes more equally than the older age cohorts. In fact, there is some evidence that men have increased the time spent on routine domestic tasks and child care and that women nowadays spend a smaller proportion of their time than they used to on routine domestic tasks (Gershuny and Robinson 1988). This has led to speculations about enhancing the caregiving responsibility of men (see Ve 1989,257). As the caregiving of women are being used up, we must turn to male caregiving potential. Thus, although younger age cohorts may be more dismissive of family care provided by women, I hypothesize that they are more likely to share the responsibility of providing family care more equally between women and men.

In contrast to the socialization hypothesis, Waerness $(1989 a, 172)$ suggests that the popularity of public rather than family care has increased rapidly during the last ten to fifteen years among elderly women. This change of attitudes has occurred because the growth of public services has reduced the total dependency of many of the elderly on practical help and support from their family. According to Waerness $(1987,142)$, this is what the elderly women have wanted more than the elderly men. In contrast to the stands women take, elderly men prefer family care. Waerness (1987, $136,142 ; 1989 a, 172)$ explains this in the following way: because men lack knowledge and experience of housework and family care at an earlier age, they are not conscious of the strain the situation may impose on close family members when they become dependent on a lot of help and care in everyday life. Therefore, they may take family care for granted to an extent that is not likely in the case of women. Moreover, the use of public care services would make men's status as dependents clearly visible.

Family care provided by a spouse will probably continue to be more important for men than for women. This is not only a result of the difference in the remarriage rate between men and women, but is also due to the usual age difference between spouses, and the longer life expectancy of women. Most married women are widowed before they become unable to manage on their own in everyday life (Waerness 1989a, 173).

Ideology. Usually, the emphasis on family care has been associated with the new Rightist attack on the welfare state. As the representatives of Rightist ideologies oppose the large scale social and welfare services provided by the state, they can also be expected to support the idea of increasing the caregiving responsibility of the family. Also the ideological views of the family are quite different between the Right and the Left. The Leftist parties have traditionally emphasized individualist family values, while 
the Rightist parties have emphasized familist values (Ervasti 1995).

There is also a clear difference in the views of gender inequality between the Right and the Left. Much too little attention has been paid to the fact that as there are several dimensions in inequality between genders, there also are several political reactions to inequality. For example, there are conservative feminists whose goal is largely limited to achieving equal access to society's rewards of money, status and power for a few privileged women. At the other end of the Right/Left political scale, there are the socialist and radical feminists who are more interested in social welfare issues, the relationship of women to the state and issues related to family and care (Bryson 1992, 47-49). Thus, I expect that the concerns of Rightist upper-class feminism can be rather removed from those of Leftist feminism.

Labor market experiences. Prior research indicates that women who are involved in paid work outside the home have a more pro-feminist outlook with regard to a range of issues (Davis and Robinson 1991; Alwin, Braun and Scott 1992, 23). Thus, I expect the full-time working women to support outside-home care for the elderly and children. Moreover, the time availability hypothesis suggests that competing time demands determine the available time and possibilities for performing caregiving tasks (see Finley 1989, 80). According to the time availability hypothesis, part-time working and nonemployed women may more easily accept the role of a family caregiver. In the present discussion it has been suggested that unemployment increases the possibilities for enhancing the caregiving responsibility of the family because of the increase in available time. It has also been argued that nonemployed women especially support traditional gender and family roles. Nonemployed women who depend on a male wage earner and who face rising divorce rates and the declining status of being a housewife may have an interest in maintaining traditional family and gender roles, and thus, have positive opinions about female family care (Gerson 1987).

Marital status. Finally, I assume that marital status has an influence on attitudes towards family care. Here the hypotheses are the most contradictory. Stoller (1983, 856 ) reports that married people provide less support for their elderly parents than do single people. Probably the caregiving potential of those who are married is used up in the sphere of the nuclear family, especially when there are children. However, it is also reasonable to expect that individuals with large families will be more willing to support family care because in large families the caregiving tasks can more easily be divided between the members of the family than in small families. Accordingly, unmarried individuals, especially those with children may be more dependent on outside-home services.

In several cases the hypotheses drawn from the previous research and discussion are contradictory. Especially in comparisons between different groups of women and men notable differences among both sexes have been found. Thus, most of the hypotheses actually describe different kinds of interaction effects of gender with other variables in attitudes towards family care. Thus, several of the above hypotheses predict different effects from the same variable on the attitudes of women and men. The hypotheses presuppose notable differences among both women and men and that the gender conflict will take a totally different form between different groups of women and men.

\section{Data and measures}

Data for this study were obtained from a postal survey conducted in Finland in the autumn 1994 as a part of the International Survey of Economic Attitudes (ISEA). The sample is a representative sample of the Finnish population aged 18 to 74 . The 
questionnaire was sent to 3,100 individuals of which 1,737 persons returned the completed questionnaire. Thus, the final response rate was 56 percent.

Independent variables. According to the hypotheses described above, I chose gender, marital status, education, employment and party affiliation as independent variables ${ }^{4}$. Two categories were used to measure marital status combining all categories of the unmarried into one. Age was measured in full years and education was measured at four levels. Labor market experiences were measured by the variable »employment», which consists of five categories, the category »other» containing all individuals who are not participating in the labor force at the moment but who are not unemployed or retired. Ideological differences were measured by the variable "party affiliation», which means the party the person voted for in the parliamentary election of 1991.

Dependent variables. Perceptions of different ways of organizing social care were measured separately for child care and care for the elderly by a total of eight items. The respondents were asked the following question concerning family care for the elderly: »How suitable do you think the following are for taking care of an elderly parent who can no longer take care of him- or herself: (a) a daughter, and (b) a son» Accordingly, the same question was asked about outside-home care: »(c) a private old age home and (d) a public old age home». The response categories and their scores were (1) not at all suitable, (2) not very suitable (3) somewhat suitable, (4) suitable and (5) the very best.

The corresponding questions were also asked about child care. The exact wording was: "Now think of a child under 3 years old. How suitable do you think each of these would be for child care during the day: (a) mother, (b) father, (c) a private day care center and (d) public day care center». The response categories and their scores were the same as with the questions about care for the elderly.

Statistical analysis. To estimate the effects of the independent variables, I employ Multiple Classification Analysis because most of the independent variables are qualitative (see Andrews et al. 1973). Ordinarily, Multiple Classification Analysis is used within the context of an additive model. However, several of my hypotheses presuppose interaction effects between gender and other independent variables. Thus, three different models were estimated for each dependent variable. Models 1 and 4 in each table present the effects of gender, marital status, age, education, employment and party affiliation to each dependent variable. ${ }^{5}$ Separate models were then estimated for men and women to examine the expected interaction effects. Estimates for women are presented in Models 2 and 5 and estimates for men in Models 3 and 6 in each table.

The results of the multivariate analysis are easy to interpret. The grand means describe the attitudes of the whole sample, men and women separately. The bigger the grand mean is, the more positive the attitudes towards the dependent variable are. A negative value of the adjusted deviation for a certain category of an independent variable means that the attitude of that sub-category is more negative than the average and, accordingly, a positive value of the adjusted deviation means an increasingly positive attitude towards the dependent variable.

${ }^{4}$ In the preliminary analyses the effects of several other independent variables were also estimated. However, income, spouse's income, spouse's level of education, occupation, number of children and presence of pre-school children proved to have no statistically significant effects on the dependent variables.

5 I found no evidence of multicollinearity among gender, marital status, age, education, employment and party affiliation. Most correlations among these variables (correlations for the qualitative variables were calculated after transforming them into dummy variables) were under .20 . The highest correlation was found between being retired and age, which was .56 , well below the .70 level suggested as grounds for concern by Hanushek and Jackson $(1977,90)$. 


\section{Results}

First, it can be stated that outside-home care is clearly more popular than family care, especially in the care for the elderly. The grand means in Tables 1 and 2 show that the most popular way of caring for the elderly are the public old age homes. However, parents are seen as the most popular caregivers for children (Tables 3 and 4). Further, the grand means show that the female caregivers - daughters for the elderly and mothers for children - are more popular caregivers than men among both female and male respondents. A clear support for the welfare state is also found in Tables 14 in the sense that both public old age homes and day-care centers are more preferable caring institutions than their private counterparts. Thus, the attack on the welfare state and the aspirations to increase family responsibility do not seem to be receiving public support. (See Appendix A for percentages.) However, there are also substantial differences in the attitudes of different sub-groups distinguished by the independent variables.

\section{Attitudes towards different ways of caring for the elderly}

The results of the multivariate analyses of attitudes towards care for the elderly are shown in Tables 1 and 2. From the women's struggle for independence hypothesis, I expected strong and significant differences between men and women in the attitudes about family care for the elderly. Surprisingly, there is no significant difference between the two sexes in attitudes towards elderly care provided by a daughter. Gender differences are greater when it comes to family care provided by a son. As expected, women are willing to increase the caring responsibility of men (Table 1). Also, women seem to prefer private old age homes more than men. When it comes to public old age homes, no significant gender effect is found (Table 2).

Thus, the women's struggle for independence does not appear in the attitudes towards filial care for the elderly. Actually the gender differences are smaller than expected. However, the other independent variables have somewhat different effects on the attitudes of men and women. There is a clear interaction effect between marital status and gender. Marital status has a greater effect on the attitudes of men than on the attitudes of women. Unmarried men support both kinds of family care more than married men (Table 1). The hypothesis, derived from Stoller's (1983) study, according to which unmarried persons favor family care, finds support in the men's attitudes but not in the women's attitudes.

Age has a strong effect on attitudes towards all kinds of care for the elderly. In the light of the socialization hypothesis I expected younger age cohorts to oppose family care provided by women. This does not hold true. On the contrary, young women think that daughters are suitable caregivers for the elderly (see Table 1). The other part of the socialization hypothesis, that younger age cohorts are more willing to share the caring tasks between men and women, seems to find some support. At least younger age cohorts of women seem to be ready to increase the caring responsibility of sons. However, between men of different ages, there is no such linear association.

According to the other hypothesis concerning age, the older men should be strongly for family care provided by women. This hypothesis receives no support. On the contrary, the oldest male cohort is more critical to care provided by a daughter than their female counterpart cohort. There is no support for Waerness's (1989a, 173) claim that the gender conflict in caring issues gets harder between elderly men and women.

The effect of age is of special interest when it comes to the question of family care and outside-home care of the elderly. The younger age groups seem to be fond of 
T a b l e 1. Attitudes towards family care for the elderly provided by a daughter (Models 1-3) and by a son (Models 4-6). Grand means, Adjusted deviations and Beta values. (Multiple Classification Analysis).

\begin{tabular}{|c|c|c|c|c|c|c|}
\hline \multirow[b]{2}{*}{ Variable } & \multicolumn{3}{|c|}{ Daughter } & \multicolumn{3}{|c|}{ Son } \\
\hline & $\begin{array}{c}\text { Model } 1 \\
\text { All }\end{array}$ & $\begin{array}{l}\text { Model } 2 \\
\text { Women }\end{array}$ & $\begin{array}{c}\text { Model } 3 \\
\text { Men }\end{array}$ & $\begin{array}{c}\text { Model } 4 \\
\text { All }\end{array}$ & $\begin{array}{l}\text { Model } 5 \\
\text { Women }\end{array}$ & $\begin{array}{c}\text { Model } 6 \\
\text { Men }\end{array}$ \\
\hline Grand mean & $3.19^{* * *}$ & $3.21^{* * *}$ & 3.16 & $2.94 * * *$ & $3.01 * * *$ & $2.88^{*}$ \\
\hline $\begin{array}{l}\text { Gender }^{1} \\
\text { Women } \\
\text { Men } \\
\text { F }\end{array}$ & $\begin{array}{r}.01 \\
.01 \\
-.01 \\
.83\end{array}$ & $\begin{array}{l}- \\
- \\
-\end{array}$ & $\begin{array}{l}- \\
- \\
-\end{array}$ & $\begin{array}{c}.04 \\
.04 \\
-.04 \\
6.40^{*}\end{array}$ & $\begin{array}{l}- \\
- \\
-\end{array}$ & $\begin{array}{l}- \\
- \\
-\end{array}$ \\
\hline $\begin{array}{l}\text { Marital status }{ }^{1} \\
\text { Married } \\
\text { Unmarried } \\
\text { F }\end{array}$ & $\begin{array}{c}.03 \\
-.02 \\
.05 \\
5.05^{*}\end{array}$ & $\begin{array}{r}.03 \\
.02 \\
-.05 \\
.09\end{array}$ & $\begin{array}{c}.12 \\
-.08 \\
.21 \\
11.75^{* *}\end{array}$ & $\begin{array}{r}.01 \\
-.01 \\
.02 \\
2.86\end{array}$ & $\begin{array}{r}.03 \\
.02 \\
-.05 \\
.48\end{array}$ & $\begin{array}{c}.09 \\
-.06 \\
.15 \\
9.06 * *\end{array}$ \\
\hline $\begin{array}{l}\text { Age }^{1} \\
\quad-25 \\
25-34 \\
35-44 \\
45-54 \\
55- \\
\text { F }\end{array}$ & $\begin{array}{r}.04 \\
.10 \\
.05 \\
-.03 \\
-.02 \\
-.03 \\
2.61 *\end{array}$ & $\begin{array}{c}.09 \\
.08 \\
.15 \\
-.09 \\
-.12 \\
.03 \\
4.26 * *\end{array}$ & $\begin{array}{r}.06 \\
.09 \\
-.07 \\
.05 \\
.06 \\
-.07 \\
.38\end{array}$ & $\begin{array}{c}.11 \\
.14 \\
.15 \\
.03 \\
-.05 \\
-.18 \\
10.95^{* * *}\end{array}$ & $\begin{array}{c}.16 \\
.16 \\
.28 \\
-.06 \\
-.14 \\
-.15 \\
10.95^{* * *}\end{array}$ & $\begin{array}{c}.11 \\
.09 \\
-.00 \\
.14 \\
.04 \\
-.18 \\
2.63^{*}\end{array}$ \\
\hline $\begin{array}{l}\text { Education }^{1} \\
\text { Less than vocational } \\
\text { Vocational } \\
\text { College } \\
\text { University degree } \\
\text { F }\end{array}$ & $\begin{array}{r}.06 \\
.11 \\
-.02 \\
-.05 \\
-.07 \\
1.22\end{array}$ & $\begin{array}{r}.10 \\
.19 \\
.01 \\
-.07 \\
-.17 \\
1.40\end{array}$ & $\begin{array}{r}.03 \\
.05 \\
-.04 \\
-.01 \\
-.00 \\
.27\end{array}$ & $\begin{array}{r}.05 \\
.08 \\
-.05 \\
-.00 \\
-.02 \\
.43\end{array}$ & $\begin{array}{r}.07 \\
.13 \\
-.04 \\
-.02 \\
-.11 \\
.28\end{array}$ & $\begin{array}{r}.04 \\
.04 \\
-.05 \\
.01 \\
.04 \\
.19\end{array}$ \\
\hline $\begin{array}{l}\text { Employment }^{1} \\
\text { Full time } \\
\text { Part time } \\
\text { Unemployed } \\
\text { Retired } \\
\text { Other } \\
\text { Party affiliation } \\
\text { Left league } \\
\text { Social democrat } \\
\text { Green league } \\
\text { Centre } \\
\text { Conservative } \\
\text { Other } \\
\text { F }\end{array}$ & $\begin{array}{r}.07 \\
-.03 \\
.10 \\
.18 \\
-.10 \\
.05 \\
.12 \\
-.36 \\
-.06 \\
.08 \\
.18 \\
-.13 \\
.07 \\
4.07 * *\end{array}$ & $\begin{array}{r}.14 \\
-.00 \\
-.04 \\
.30 \\
-.34 \\
.08 \\
.17 \\
-.46 \\
-.18 \\
.08 \\
.25 \\
-.18 \\
.13 \\
3.93^{* *}\end{array}$ & $\begin{array}{r}.07 \\
-.03 \\
.33 \\
.03 \\
.07 \\
-.07 \\
.09 \\
-.30 \\
.01 \\
.10 \\
.13 \\
-.07 \\
.01 \\
1.19\end{array}$ & $\begin{array}{r}.06 \\
-.00 \\
.08 \\
.07 \\
-.14 \\
.06 \\
.12 \\
-.23 \\
-.12 \\
.16 \\
.16 \\
-.13 \\
.09 \\
4.85^{* *}\end{array}$ & $\begin{array}{r}.15 \\
.05 \\
-.03 \\
.21 \\
-.38 \\
.04 \\
.15 \\
-.35 \\
-.19 \\
.14 \\
.20 \\
-.12 \\
.09 \\
3.18^{* *}\end{array}$ & $\begin{array}{r}.06 \\
-.02 \\
.27 \\
-.09 \\
.03 \\
.02 \\
.11 \\
-.16 \\
-.08 \\
.19 \\
.14 \\
-.13 \\
-.08 \\
1.77\end{array}$ \\
\hline $\mathrm{R}$ & .177 & .267 & .173 & .229 & .307 & .202 \\
\hline
\end{tabular}

Levels of significance $*<.05 ; * *<.01 ; * * *<.001$.

') Beta values in bold.

private outside-home care. The older age cohorts support public outside-home care. Thus, the older age cohorts seem to support the welfare state in terms of care for the elderly (Table 2).

From the hypotheses about the effects of education, I expected the support of family care to lessen at the higher levels of education. This seems to hold true, but the differences are not statistically significant (Table 1). Significant differences according to education levels can only be found in the questions of outside-home care for the elderly (Table 2). Education also has the effect of increasing the support of private out- 
T a b l e 2. Attitudes towards private (Models 1-3) and public (Models 4-6) outsidehome care for the elderly. Grand means, Adjusted deviations and Beta values. (Multiple Classification Analysis).

Private old age home

Variable

Grand mean
Gender $^{1}$
Women
Men
F

Marital status ${ }^{1}$

Married

Unmarried

F

$$
\text { Age }^{1}
$$

-25
$25-34$
$35-44$
$45-54$
$55-$
$F$

Education $^{1}$

Less than vocational

Vocational

College

University degree

F
Employment ${ }^{1}$
Full time
Part time
Unemployed
Retired
Other
$\mathrm{F}$

Party affiliation ${ }^{1}$

Left league

Social democrat

Green league

Centre

Conservative

Other

F

$\mathrm{R}$

$\begin{array}{ccc}\text { Model } 1 & \text { Model } 2 & \text { Model } 3 \\ \text { All } & \text { Women } & \text { Men }\end{array}$

$3.41 * * * \quad 3.53 * * * \quad 3.29 * * *$

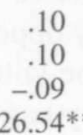

.03

.01

$-.04$

.00

.13

.29

.09

$-.12$

$-.09$

$-.01$

$7.75 * * *$

.09

$-.07$

$-.07$

.10

.08

$8.30 * * *$

.05

.03

.09

$-.01$

$-.10$

.00

.88

\section{.17}

$-.31$

$-.15$

$-.00$

$-.02$

.26

$-.01$

$8.12 * * *$

.291

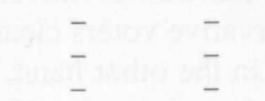

.07

.04

$-.10$

1.45

.16

.37

.05

$-.17$

$-.03$

$-.02$

$6.62 * * *$

\begin{abstract}
.09
\end{abstract}
$-.09$

$-.01$

.09

.02

$3.55 * *$

.07

.02

.10

$-.05$

$-.14$

.04

.59

.18

$-.34$

$-.21$

.06

$-.10$

.24

.04

$4.42 * *$

.298
Public old age home

$\begin{array}{ccc}\text { Model } 4 & \text { Model } 5 & \text { Model } 6 \\ \text { All } & \text { Women } & \text { Men }\end{array}$

$3.78 * * * \quad 3.78 * * \quad 3.77 * * *$

$\begin{array}{rrr}.03 & - & - \\ .03 & - & - \\ -.02 & - & - \\ .01 & - & - \\ .01 & .02 & .02 \\ .00 & .01 & -.01 \\ -.01 & -.03 & .02 \\ 2.94 & .61 & 2.69 \\ .13 & .12 & .15 \\ -.20 & -.14 & -.25 \\ -.16 & -.15 & -.18 \\ .08 & .12 & .04 \\ .01 & -.02 & .04 \\ .14 & .12 & .14 \\ 12.27 * * * & 5.05 * * & 6.78 * * *\end{array}$

$\begin{array}{rrr}.03 & .07 & .08 \\ -.01 & -.09 & .07 \\ -.01 & .10 & -.08 \\ -.02 & -.02 & -.01 \\ .03 & .02 & .05\end{array}$

$1.45 \quad .89 \quad 3.04$ *

$\begin{array}{lll}.07 & .08 & .09\end{array}$

$\begin{array}{lll}.00 & -.04 & .04\end{array}$

$\begin{array}{lll}-.09 & -.00 \quad-.22\end{array}$

$\begin{array}{lll}-.05 & -.04 & -.04\end{array}$

$\begin{array}{lll}.11 \quad .06 & .06\end{array}$

$\begin{array}{lll}-.07 & -.03 & -.14\end{array}$

$\begin{array}{lll}1.06 & .59 & 1.38\end{array}$

$\begin{array}{lll}.10 & .11 \quad .12\end{array}$

$\begin{array}{lll}.18 & .11 \quad .21\end{array}$

$\begin{array}{lll}.12 & .12 \quad .13\end{array}$

$\begin{array}{lll}-.08 & -.08 & -.04\end{array}$

$\begin{array}{lll}-.15 & -.17 & -.15\end{array}$

$\begin{array}{lll}.01 & .10 \quad-.10\end{array}$

$\begin{array}{lll}-.02 & -.04 & .00\end{array}$

$3.19 * * \quad 1.75 \quad 2.39 *$

$\begin{array}{lll}.222 & .218 \quad .266\end{array}$

Levels of significance $*<.05 ; * *<.01 ; * * *=.001$.

$\left.{ }^{1}\right)$ Beta values in bold.

side-home caring. However, it should also be noted that this is not evident as a decrease in the support of public outside-home caring. Evidently, people do not see public and private care for the elderly as opposite alternatives. Support for private old age homes does not appear as opposition to public old age homes.

Employment and labor market experiences have only a few significant effects on attitudes towards care for the elderly. According to the time availability hypothesis, involvement in part-time work should increase female support of family care. This does not hold true. On the contrary, working part-time seems to increase male support for 
family care. However, unemployment seems to increase female support for family care (Table 1).

The effects of party affiliation are almost all statistically significant. The voters for the Leftist parties seem to be quite critical towards all other ways of caring for the elderly except public old age homes. A little surprisingly, the voters for the Conservative party also come very close to the views of the voters of the Leftist parties. Only when it comes to public care for the elderly is there a clear difference between the voters for the Leftist parties and the Conservatives. Here we should pay attention to the fact that only the male Conservative voters clearly oppose care for the elderly provided by public old age homes. On the other hand, the voters for the Green party and for the Center party share the same opinion in elderly care issues. An interesting detail is that the voters and especially female voters for the Center party most strongly oppose public care for the elderly.

\section{Attitudes towards different ways to arrange child care}

The results of the multivariate analysis on the attitudes towards different ways of caring for children are shown in Tables 3 and 4 . This time there are clear differences between the two sexes. Men seem to prefer family care provided by mothers more than women and to oppose care provided by fathers more than women. As far as child care is concerned, the women's struggle for independence hypothesis finds support. In addition, women support both public and private outside-home care more than men. However, married women favor maternal care more than unmarried women.

There are also clear differences according to age. The socialization hypothesis receives support. Younger age groups are more critical than the older groups to maternal care but more in favor of paternal care than older groups. The younger age cohorts support both private and public outside-home child care more than the older cohorts.

Surprisingly, employment has no significant effects on attitudes towards child care. However, there is a slight tendency for those working part-time and for the nonemployed to prefer family care and for those employed full-time to prefer outside-home care.

Again, party affiliation is a significant factor. This time there is a greater difference between the two Leftist parties. The voters for both Leftist parties prefer outside-home care to family care, but the voters for the Left-Wing League are clearly more critical than the Social Democrats about private day care centers. Supporters of the Green party are now nearer the Leftist parties. There seems to be a big difference for the Greens between child care and care for the elderly. The voters for the Center party are again clearly for family care and against outside-home care. The opinions of the Conservatives are not surprising. The Conservatives oppose family care, especially when it is provided by the father. Probably, this is a reflection of the traditional Conservative view of the family. Also, Conservative voters are more in favor of private day care centers than voters of other parties.

\section{Discussion}

As a solution to the crisis of the welfare state an enhancement of the caring responsibilities of the family has been suggested. However, not much attention has been paid to public opinion about family care. In this study I have tested several hypotheses as to which groups of the population are in favor of family care. The main result is that compared to outside-home care and especially publicly provided outside-home 
$\mathrm{T}$ a b l e 3. Attitudes towards family care for children provided by a mother (Models 1-3) and by a father (Models 4-6). Grand means, Adjusted deviations and Beta values. (Multiple Classification Analysis).

\begin{tabular}{|c|c|c|c|c|c|c|}
\hline \multirow[b]{2}{*}{ Variable } & \multicolumn{3}{|c|}{ Mother } & \multicolumn{3}{|c|}{ Father } \\
\hline & $\begin{array}{r}\text { Model } 1 \mathrm{M} \\
\text { All }\end{array}$ & $\begin{array}{l}\text { Model } 2 \text { Mc } \\
\text { Women }\end{array}$ & $\begin{array}{r}\text { odel } 3 \\
\text { Men }\end{array}$ & $\begin{array}{r}\text { Model } 4 \\
\text { All }\end{array}$ & $\begin{array}{l}\text { Todel } 5 \text { M } \\
\text { Women }\end{array}$ & $\begin{array}{r}\text { Model } 6 \\
\text { Men }\end{array}$ \\
\hline Grand mean & $4.68^{* * *}$ & $4.64 * * *$ & $4.71 * *$ & $4.15^{* * *}$ & $4.20^{* * *}$ & $4.10^{* * *}$ \\
\hline $\begin{array}{l}\text { Gender }^{1} \\
\text { Women } \\
\text { Men } \\
\text { F }\end{array}$ & $\begin{array}{c}.04 \\
-.03 \\
.02 \\
6.18^{*}\end{array}$ & $\begin{array}{l}- \\
- \\
-\end{array}$ & $\begin{array}{l}- \\
- \\
-\end{array}$ & $\begin{array}{c}.07 \\
.06 \\
-.05 \\
7.10^{* *}\end{array}$ & $\begin{array}{l}- \\
- \\
-\end{array}$ & $\begin{array}{l}- \\
- \\
-\end{array}$ \\
\hline $\begin{array}{l}\text { Marital status }{ }^{1} \\
\text { Married } \\
\text { Unmarried } \\
\text { F }\end{array}$ & $\begin{array}{r}.03 \\
.01 \\
-.03 \\
.84\end{array}$ & $\begin{array}{c}.08 \\
.03 \\
-.08 \\
4.05^{*}\end{array}$ & $\begin{array}{r}.04 \\
-.02 \\
.04 \\
.55\end{array}$ & $\begin{array}{r}.03 \\
.02 \\
-.04 \\
.05\end{array}$ & $\begin{array}{r}.04 \\
.02 \\
-.05 \\
.60\end{array}$ & $\begin{array}{r}.02 \\
.01 \\
-.03 \\
1.15\end{array}$ \\
\hline $\begin{array}{l}\text { Age }^{1} \\
-25 \\
25-34 \\
35-44 \\
45-54 \\
55- \\
\text { F }\end{array}$ & $\begin{array}{l}.12 \\
-.06 \\
-.09 \\
-.06 \\
.04 \\
.11 \\
5.42^{* * *}\end{array}$ & $\begin{array}{c}.12 \\
-.06 \\
-.07 \\
-.07 \\
.06 \\
.11 \\
2.64 *\end{array}$ & $\begin{array}{l}.15 \\
-.08 \\
-.12 \\
-.04 \\
.02 \\
.12 \\
3.47^{* *}\end{array}$ & $\begin{array}{c}.15 \\
.19 \\
.09 \\
.08 \\
-.09 \\
-.15 \\
12.14 * * *\end{array}$ & $\begin{array}{l}.11 \\
.18 \\
.09 \\
-.03 \\
-.09 \\
-.05 \\
5.40^{* * *}\end{array}$ & $\begin{array}{l}.21 \\
.20 \\
.07 \\
.19 \\
-.09 \\
-.21 \\
8.45^{* * *}\end{array}$ \\
\hline $\begin{array}{l}\text { Education }^{1} \\
\text { Less than vocational } \\
\text { Vocational } \\
\text { College } \\
\text { University degree } \\
\text { F }\end{array}$ & $\begin{array}{c}.13 \\
.06 \\
.05 \\
-.01 \\
-.20 \\
14.17^{* * *}\end{array}$ & $\begin{array}{c}.17 \\
.07 \\
.07 \\
.03 \\
-.26 \\
10.45^{* * *}\end{array}$ & $\begin{array}{l}.11 \\
.06 \\
.03 \\
-.06 \\
-.13 \\
5.57^{* * *}\end{array}$ & $\begin{array}{l}.09 \\
.04 \\
.07 \\
-.03 \\
-.14 \\
4.49 * *\end{array}$ & $\begin{array}{l}.12 \\
.02 \\
.10 \\
.02 \\
-.21 \\
2.65^{*}\end{array}$ & $\begin{array}{l}.09 \\
.06 \\
.04 \\
-.11 \\
-.05 \\
3.02 *\end{array}$ \\
\hline $\begin{array}{l}\text { Employment }^{1} \\
\text { Full time } \\
\text { Part time } \\
\text { Unemployed } \\
\text { Retired } \\
\text { Other } \\
\text { F }\end{array}$ & $\begin{array}{r}.06 \\
-.03 \\
.09 \\
.08 \\
.01 \\
.01 \\
1.43\end{array}$ & $\begin{array}{r}.07 \\
-.04 \\
.06 \\
.11 \\
-.02 \\
.02 \\
.91\end{array}$ & $\begin{array}{r}.05 \\
-.01 \\
.13 \\
.03 \\
.02 \\
-.03 \\
.56\end{array}$ & $\begin{array}{r}.03 \\
-.00 \\
.03 \\
.01 \\
-.05 \\
.04 \\
.21\end{array}$ & $\begin{array}{r}.12 \\
.05 \\
.07 \\
-.04 \\
-.22 \\
.03 \\
1.09\end{array}$ & $\begin{array}{r}.05 \\
-.04 \\
-.00 \\
.03 \\
.06 \\
.03 \\
.46\end{array}$ \\
\hline $\begin{array}{l}\text { Party affiliation }{ }^{1} \\
\text { Left league } \\
\text { Social democrat } \\
\text { Green league } \\
\text { Centre } \\
\text { Conservative } \\
\text { Other } \\
\text { F }\end{array}$ & $\begin{array}{r}.11 \\
-.03 \\
.00 \\
-.18 \\
.05 \\
-.07 \\
.07 \\
3.82 * *\end{array}$ & $\begin{array}{r}.17 \\
-.13 \\
.03 \\
-.25 \\
.11 \\
-.09 \\
.07 \\
3.98^{* *}\end{array}$ & $\begin{array}{r}.08 \\
.03 \\
-.03 \\
-.02 \\
-.00 \\
-.06 \\
.07 \\
.93\end{array}$ & $\begin{array}{r}.12 \\
-.06 \\
.03 \\
-.08 \\
.08 \\
-.17 \\
.08 \\
4.25^{* *}\end{array}$ & $\begin{array}{r}.14 \\
-.34 \\
.01 \\
-.09 \\
.08 \\
-.12 \\
.09 \\
2.56 *\end{array}$ & $\begin{array}{r}.14 \\
.07 \\
.03 \\
-.05 \\
.08 \\
-.21 \\
.07 \\
2.84 *\end{array}$ \\
\hline $\mathrm{R}$ & .260 & .318 & .229 & .247 & .260 & .277 \\
\hline
\end{tabular}

Levels of significance $*<.05 ; * *<.01 ; * * *<.001$.

$\left.{ }^{1}\right)$ Beta values in bold.

care, family care does not receive public support as a general solution to the caring problems of society. However, there are clear differences between the attitudes towards care for the elderly and care for children. Family care for children clearly finds more support from both men and women than does family care for the elderly.

The women's struggle for independence hypothesis suggests that the question of increasing family care is mainly a reflection of the gender conflict in our society. This hypothesis is not completely supported by my analysis. There are great differences be- 
T a b l e 4. Attitudes towards private (Models 1-3) and public (Models 4-6) outsidehome care for children. Grand means, Adjusted deviations and Beta values. (Multiple Classification Analysis).

\begin{tabular}{|c|c|c|c|c|c|c|}
\hline \multirow[b]{2}{*}{ Variable } & \multicolumn{3}{|c|}{ Private day care center } & \multicolumn{3}{|c|}{ Public day care center } \\
\hline & $\begin{array}{c}\text { Model } 1 \\
\text { All }\end{array}$ & $\begin{array}{l}\text { Model } 2 \\
\text { Women }\end{array}$ & $\begin{array}{c}\text { Model } 3 \\
\text { Men }\end{array}$ & $\begin{array}{l}\text { Model } 4 \\
\text { All }\end{array}$ & $\begin{array}{l}\text { Model } 5 \\
\text { Women }\end{array}$ & $\begin{array}{c}\text { Model } 6 \\
\text { Men }\end{array}$ \\
\hline Grand mean & $3.35 * * *$ & $3.50^{*}$ & $3.22 * * *$ & $3.53^{* * *}$ & $3.66 * *$ & $3.40^{* * *}$ \\
\hline $\begin{array}{l}\text { Gender }^{1} \\
\text { Women } \\
\text { Men } \\
\text { F }\end{array}$ & $\begin{array}{c}.17 \\
.14 \\
-.13 \\
49.74^{* * *}\end{array}$ & $\begin{array}{l}- \\
- \\
-\end{array}$ & $\begin{array}{l}- \\
- \\
-\end{array}$ & $\begin{array}{c}.17 \\
.15 \\
-.14 \\
35.92^{* * *}\end{array}$ & $\begin{array}{l}- \\
- \\
-\end{array}$ & $\begin{array}{l}- \\
- \\
-\end{array}$ \\
\hline $\begin{array}{l}\text { Marital status }{ }^{1} \\
\text { Married } \\
\text { Unmarried } \\
\text { F }\end{array}$ & $\begin{array}{r}.03 \\
-.02 \\
.04 \\
1.95\end{array}$ & $\begin{array}{r}.04 \\
-.02 \\
.04 \\
2.16\end{array}$ & $\begin{array}{r}.02 \\
-.01 \\
.03 \\
.30\end{array}$ & $\begin{array}{r}.05 \\
-.03 \\
.06 \\
.75\end{array}$ & $\begin{array}{r}.07 \\
-.04 \\
.09 \\
1.97\end{array}$ & $\begin{array}{r}.03 \\
-.02 \\
.05 \\
.02\end{array}$ \\
\hline $\begin{array}{l}\text { Age }^{1} \\
\quad-25 \\
25-34 \\
35-44 \\
45-54 \\
55- \\
\text { F }\end{array}$ & $\begin{array}{l}.10 \\
.18 \\
.07 \\
-.00 \\
-.08 \\
-.06 \\
2.57 * * *\end{array}$ & $\begin{array}{r}.15 \\
.29 \\
.06 \\
-.07 \\
-.07 \\
-.05 \\
2.44 *\end{array}$ & $\begin{array}{r}.10 \\
.11 \\
.08 \\
.07 \\
-.11 \\
-.06 \\
1.58\end{array}$ & $\begin{array}{r}.08 \\
.03 \\
-.01 \\
.11 \\
-.03 \\
-.07 \\
2.88 *\end{array}$ & $\begin{array}{r}.11 \\
.10 \\
.04 \\
.11 \\
-.06 \\
-.15 \\
1.56\end{array}$ & $\begin{array}{r}.07 \\
-.02 \\
-.06 \\
.10 \\
-.00 \\
-.03 \\
1.87\end{array}$ \\
\hline $\begin{array}{l}\text { Education }^{1} \\
\text { Less than vocational } \\
\text { Vocational } \\
\text { College } \\
\text { University degree } \\
\text { F }\end{array}$ & $\begin{array}{r}.02 \\
-.00 \\
-.02 \\
.00 \\
.04 \\
1.96\end{array}$ & $\begin{array}{r}.05 \\
.02 \\
.06 \\
-.02 \\
-.06 \\
.25\end{array}$ & $\begin{array}{r}.08 \\
-.03 \\
-.06 \\
.03 \\
.13 \\
2.81^{*}\end{array}$ & $\begin{array}{r}.02 \\
.01 \\
.01 \\
-.02 \\
.02 \\
.14\end{array}$ & $\begin{array}{r}.06 \\
-.01 \\
.05 \\
-.01 \\
.03 \\
.62\end{array}$ & $\begin{array}{r}.03 \\
.01 \\
.00 \\
-.04 \\
.01 \\
.26\end{array}$ \\
\hline $\begin{array}{l}\text { Employment }{ }^{1} \\
\text { Full time } \\
\text { Part time } \\
\text { Unemployed } \\
\text { Retired } \\
\text { Other } \\
\text { F }\end{array}$ & $\begin{array}{r}.07 \\
.06 \\
-.05 \\
-.11 \\
-.06 \\
-.03 \\
2.08\end{array}$ & $\begin{array}{r}.10 \\
.08 \\
-.08 \\
-.12 \\
-.05 \\
-.05 \\
1.55\end{array}$ & $\begin{array}{r}.07 \\
.04 \\
-.00 \\
-.11 \\
-.06 \\
-.01 \\
.86\end{array}$ & $\begin{array}{r}.09 \\
.02 \\
-.15 \\
-.11 \\
.12 \\
-.07 \\
2.08\end{array}$ & $\begin{array}{r}.11 \\
.05 \\
-.12 \\
-.14 \\
.15 \\
-.09 \\
1.70\end{array}$ & $\begin{array}{r}.07 \\
.00 \\
-.20 \\
-.07 \\
.10 \\
-.04 \\
.88\end{array}$ \\
\hline $\begin{array}{l}\text { Party affiliation } \\
\text { Left league } \\
\text { Social democrat } \\
\text { Green league } \\
\text { Centre } \\
\text { Conservative } \\
\text { Other } \\
\text { F }\end{array}$ & $\begin{array}{r}.13 \\
-.22 \\
.03 \\
.08 \\
-.07 \\
.15 \\
-.08 \\
4.55^{* * *}\end{array}$ & $\begin{array}{r}.14 \\
-.13 \\
.00 \\
.13 \\
-.14 \\
.16 \\
-.06 \\
2.67 *\end{array}$ & $\begin{array}{r}.13 \\
-.25 \\
.05 \\
.05 \\
-.01 \\
.14 \\
-.10 \\
2.31 *\end{array}$ & $\begin{array}{c}.17 \\
.34 \\
.17 \\
.02 \\
-.15 \\
.06 \\
-.14 \\
8.55^{* * *}\end{array}$ & $\begin{array}{c}.19 \\
.57 \\
.16 \\
.01 \\
-.15 \\
.09 \\
-.14 \\
5.19 * * *\end{array}$ & $\begin{array}{c}.15 \\
.20 \\
.17 \\
.03 \\
-.13 \\
.04 \\
-.13 \\
3.41 * *\end{array}$ \\
\hline $\mathrm{R}$ & .254 & .213 & .204 & .252 & .242 & .192 \\
\hline
\end{tabular}

Levels of significance $*<.05 ; * *<.01 ; * * *<.001$.

1) Beta values in bold.

tween the two genders in attitudes towards different caring systems, but in several cases the differences among both men and women are larger than differences between the sexes. And even more importantly, there are several groups of women who are more in favor of family care than their male counterparts. A general female interest cannot be found.

The socialization hypothesis gets more support than the women's struggle hypothesis. Younger age cohorts have evidently been socialized into more equal gender roles 
for caring activities than the older age cohorts. This means that the gender conflict is more likely to vanish than to become stronger.

The time availability hypothesis suggests that increasing unemployment makes family care more common and more acceptable. According to my analysis, this does not hold true. In some cases, unemployment does increase support for family care, but the effects of unemployment were not large and most importantly, they were not statistically significant. Probably, even high levels of unemployment do not make the strategy of family care more possible.

Again, as so often when different strategies of social policy are considered, political affiliation was an important independent variable. The voters for the Center party compose the group most eager to enhance family responsibility for caring activities. Traditionally, the voters for the Center party are farmers who do not need outsidehome services as much as wage earners in urban surroundings. However, the Finnish Conservative voters are not attracted by the family option. More evidently, the popularity of private services is high among the Conservatives. In any case the Conservatives, too, do want to maintain outside-home services.

The policy implications of my analysis are clear. Increasing the responsibility of the family in care for the elderly and children will hardly be a successful policy. Public opinion does not support the family-oriented strategy. The strategy of increasing family responsibility - at least as far as it is accomplished by dismantling the caring systems of the welfare state - will probably be met with opposition.

Although a rhetorical extolling of the virtues of family care may be convincing and even politically successful, in practice a replacement of the welfare state by the family is hardly possible. However, this conclusion does not rely on finding declining caring potential of the family. For example, the popularity of maternal and even parental child care shows that people still think that family members are the most suitable caregivers. The simultaneous support especially for public outside-home services can be interpreted as a sign that families need outside-home help in carrying out their caring tasks. Thus, introducing new family care-oriented policies and cuts in the public welfare services could even be counterproductive. Families would soon be overloaded with caring tasks. This would probably cause a variety of domestic and familial problems similar to those that the most eager representatives of family-oriented social policy have usually blamed on the welfare state. But also, and what the critics of the welfare state have not noticed, this overloading of the family would manifestly lead to a poor quality of family care (see Finch 1989; Roberts 1984). As a result, the family would offer an increasingly poorer alternative to the welfare state.

\section{References}

Alwin, D., M. Braun and J. Scott. 1992. The separation of work and the family: attitudes towards women's labor-force participation in Germany, Great Britain, and the United States. European Sociological Review 8(1):13-37.

Andrews, F., J. Morgan, J. Sonquist and L. Klem. 1973. Multiple classification analysis. Ann Arbor, MI: Institute for Social Research.

Boh, K.1989. European family life patterns - a reappraisal. In: Changing Patterns of European Family Life: A Comparative Analysis of 14 European Countries, edited by K. Boh, M. Bak, C. Clason, M. Pankratova, J. Qvortrup, G.B. Sgritta and K. Waerness, pp. 265-298. London: Routledge.

Bryson, L. 1992. Welfare and the State: Who Benefits? Basingstoke: Macmillan.

Bumpass, L. 1990. What's happening to the family? Interactions between demographic and institutional change. Demography 27(4):483-498.

Castro, Martin, T. and L. Bumpass. 1989. Recent trends in marital disruption. Demography 26(1): 37-51.

Dahlström, E. 1989. Theories and ideologies of family functions, gender relations and human repro- 
duction. In: Changing Patterns of European Family Life: A comparative Analysis of 14 European Countries edited by K. Boh et al., pp. 31-51. London: Routledge.

Davis, N. and R.Robinson. 1991. Men's and women's consciousness of gender inequality: Austria, West Germany, Great Britain and the United States. American Sociological Review, 56(1):7284.

Desai, S. and L. Waite. 1991. Women's employment during pregnancy and after the first birth: occupational characteristics and work commitment. American Sociological Review 51(4):551566.

Ervasti, H. 1994. Yhteiskuntaluokat ja hyvinvointipalvelu (Social classes and welfare services). Sosiologia 31(4):274-287.

Ervasti, H. 1995. Puolueet ja päivähoito - näkökulma palvelujärjestelmän kehitykseen (Party strategies and day care for children - a case study of the development of social services). Janus 3(3), (forthcoming).

Ervasti, H. and O. Kangas. 1995. The class bases of universal social policy. European Journal of Political Research 27(3).

Farkas, G. 1976. Education, wage rates, and the division of labor between husband and wife. Journal of Marriage and the Family 38(3): 473-483.

Finch, J. 1989. Family Obligations and Social Change. Cambridge: Polity Press.

Finch, J. 1989a. Social policy, social engineering and the family in the 1990s. In: The Goals of Social Policy, edited by M. Bulmer, J. Lewis and D. Piachaud, pp. 160-169. London: Unwin Hyman.

Finley, N. 1989. Theories of family labor as applied to gender differences in caregiving for elderly parents. Journal of Marriage and the Family 51(1):79-86.

Gershuny, J. and J. Robinson. 1988. Historical changes in the household division of labor. Demography 25(4):537-552.

Gerson, K. 1987. Emerging social divisions among women: implications for welfare state politics. Politics \& Society $15(2): 213-221$.

Goldthorpe, J. 1987. Family Life in Western Societies. Cambridge: Cambridge University Press.

Hadley, R. and S. Hatch. 1981. Social Welfare and the Failure of the State. London: George Allen \& Unwin.

Hanushek, E.A. and J.E. Jackson. 1977. Statistical Methods for Social Scientists. London: Academic Press.

Hulkko, Jouko. 1990. Family policy in Western Europe. Yearbook of Population Research in Finland 28:5-27.

Kamerman, S.and A. Kahn. 1989. Single-parent, female headed families in Western Europe: social change and response. International Social Security Review 42(1):3-34.

Kramer, R. 1983. In Defense of the Family. New York: Basic Books.

Lewis, J. 1989. Introduction. In: The Goals of Social Policy, edited by M. Bulmer, J. Lewis and D. Piachaud, pp. 131-140. London: Unwin Hyman.

Lindbeck, A. 1986. Limits to the Welfare State. Challenge 28 (January-February):31-45.

Lindgren, Jarl and Marketta Ritamies. 1994. Parisuhteet ja perhe (Conjugal unions and the family) In: Suomen väestö, edited by S. Koskinen, T. Martelin, I-L Notkola, V. Notkola and K. Pitkänen, pp. 107-149. Helsinki: Gaudeamus.

Lindgren, Jarl and Marketta Ritamies. 1987. The European below replacement fertility decline. Yearbook of Population Research in Finland 25:30-39.

Parsons, T. and R. Bales. 1955. Family: Socialization and Interaction Process. London: Routledge and Kegan Paul.

Presser, H. 1989. Can we make time for children? The economy, work schedules, and child care. Demography 26(4):523-543.

Roberts, E. 1984. A Woman's Place. Oxford: Basil Blackwell.

Saari, Matti. 1992. The development of family structure in Finland in 1960-1987. Yearbook of Population Research in Finland 30:5-17.

Scott, J. and M. Braun and D. Alwin. 1993. The family way. In: International Social Attitudes. The 10th BSA Report, edited by R. Jowell, L. Brook and L.Dowds, pp. 23-48. Aldershot: Gover.

Stoller, E. 1983. Parental caregiving by adult children. Journal of Marriage and the Family 45(4):851858.

Svallfors, S. 1989. Vem älskar välfardstaten? Lund: Arkiv.

Taylor-Gooby, P. 1991. Social Change, Social Welfare and Social Science. London: Harvester Wheatsheaf.

Thornton, A., D. Alwin and D. Camburn. 1983. Causes and consequences of sex-role attitudes and attitude change. American Sociological Review 48:211-227.

Vanhuusbarometri 1994. (Old Age Barometer 1994) Sosiaali- ja terveysministeriön selvityksiä 1994:6. Helsinki: Sosiaali- ja terveysministeriö. 
Waerness, K. 1987. A feminist perspective on the new ideology of 'community care' for the elderly. Acta Sociologica 30(2):133-150.

Waerness, K. 1989. Caring. In: Changing Patterns of European Family Life: A Comparative Analysis of 14 European Countries, edited by K. Boh et al., pp. 217-248. London: Routledge

Waerness, K. 1989a. Dependency in the welfare state. In: The Goals of Social Policy, edited by M. Bulmer, J. Lewis and D. Piachaud, pp. 170-175. London: Unwin Hyman.

$\mathrm{Ve}, \mathrm{H}$. 1989. The male gender role and responsibility for childcare. In: Changing Patterns of European Family Life: A Comparative Analysis of 14 European Countries, edited by K. Boh, pp. 249261. London: Routledge

\section{Appendix A.}

Attitudes towards different ways of caring for the elderly and children $(N=1737)$. Percentages perceiving that the named caregiver is the very best or suitable to care for the elderly and children.

\begin{tabular}{|c|c|c|c|c|c|c|}
\hline Care for the elderly & Daughter & Son & $\begin{array}{l}\text { Other } \\
\text { relative }\end{array}$ & $\begin{array}{l}\text { Private } \\
\text { old age } \\
\text { home }\end{array}$ & $\begin{array}{l}\text { Public } \\
\text { old age } \\
\text { home }\end{array}$ & $\begin{array}{l}\text { Friend, } \\
\text { neighbor } \\
\text { or col- } \\
\text { league }\end{array}$ \\
\hline All & 42 & 33 & 16 & 48 & 63 & 10 \\
\hline Women & 44 & 36 & 19 & 53 & 62 & 13 \\
\hline Men & 41 & 29 & 13 & 44 & 64 & 8 \\
\hline Child care & Mother & Father & $\begin{array}{l}\text { Grand- } \\
\text { mother, } \\
\text { aunt or } \\
\text { cousin }\end{array}$ & $\begin{array}{c}\text { Private } \\
\text { day care } \\
\text { center }\end{array}$ & $\begin{array}{l}\text { Public } \\
\text { day care } \\
\text { center }\end{array}$ & $\begin{array}{c}\text { Regulated } \\
\text { (public) } \\
\text { family } \\
\text { day care }\end{array}$ \\
\hline All & 94 & 84 & 38 & 44 & 53 & 56 \\
\hline Women & 93 & 85 & 43 & 52 & 61 & 63 \\
\hline Men & 95 & 82 & 33 & 37 & 47 & 49 \\
\hline
\end{tabular}

